\title{
РЕГІОНАЯБНИЙ РОЗВИТОК
}

UDC 338.482.22:616.9-06

MYKHAILICHENKO Hanna,

DSc (Economics), Docent, Professor

of Tourism and Recreation Department,

Kyiv National University of Trade and Economics

Kioto str.,19, Kyiv, 02156, Ukraine

E-mail: g.mykhajlichenko@knute.edu.ua

ORCID: http://orcid.org/0000-0001-7066-6527
DOI: http://doi.org/10.31617/visnik.knute.2020(130)03

KRAVTSOV Sergiy,

$\mathrm{PhD}$ (State Administration), Docent of Tourism and Recreation Department, Kyiv National University of Trade and Economics Kioto str.,19, Kyiv, 02156, Ukraine

E-mail:s.kravtsov@knute.edu.ua ORCID: http://orcid.org/0000-0002-2016-1974

ZABALDINA Yuliia,

$\mathrm{PhD}$ (Economics), Docent, Docent of Tourism and Recreation Department, Kyiv National University of Trade and Economics, Ukraine Kioto str., 19, Kyiv, 02156, Ukraine

E-mail:y.zabaldina@knute.edu.ua ORCID: http://orcid.org/0000-0003-2741-5604

\section{PIANNING OF EVENT PORTFOLIO FOR TORISM DESTINATION IN POST-QUARANTINE PERIOD}

The article deals with the sense and structure of a tourism destination event portfolio. The theoretical foundation of the planning process for Ukrainian destinations event portfolio destinations as a component of their tourism product has been carried out. The goals of forming a destination's event portfolio within the framework of the tourism product strategy and marketing strategy are determined. The factors of decision making about the structure of an event portfolio, dynamics of measures are highlighted. Proportionality of Ukrainian's destinations event portfolio is analyzed.

Keywords: destination, events, event tourism, event portfolio, tourist product, hallmark, tourist flow, tourist arrivals.

Михайличенко А., Кравцов С., Забалдина Ю. Планирование ивентивного портфеля туристической дестинации в посткарантинный период. Рассмотрены сущность и составляющие ивентивного портфеля туристической дестинации (ИПД). Осуществлено теоретическое обоснование процесса планирования ИПд Украины как составляющей их туристического продукта. Определены цели формирования ИПД в рамках маркетинговой стратегии. Выделены факторы принятия решений по структуре ивентивного портфеля, динамике мероприятий. Проанализирован состав услуг, тематика ивентивных портфелей туристических дестинаций Украины.

Ключевые слова: дестинации, ивент, ивентивный туризм, ивентивный портфель, туристический продукт, холмарк, туристический поток, туристические прибытия.

(C) Mykhailichenko H., Kravtsov S., Zabaldina Y., 2020

$36=$ ISSN 1727-9313. ВIСНИК КНТЕУ. 2020. № 2 
Background. Nowadays, one of the most dynamically growing segments of international tourism is eventual or event tourism, which is considered by many scholars and practitioners as a real opportunity to increase tourism flows and, accordingly, to ensure sustainable socio-economic effects for the territory. Carrying out mass events of different subjects can create a certain level of awareness of the target audiences about the territory when the destination is in the early stages of its like cycle, to accumulate additional tourist flows through the diversification of the offer to more developed destinations, to determine the tourist specialization of the territory. Since the 1980s, events have become an inalienable part of the local tourism product and an element of marketing strategies for many destinations around the world. Such trends in the diversification of the tourism product of the destination are particularly relevant in the post-crisis period of tourism reincarnation after significant stagnation during the quarantine measures of the pandemic coronavirus infection in 2020. The effectiveness of event programs as an element of the MICE industry can be the impetus for restoring the attractiveness of the tourism destinations in the world.

This set the task for the experts to develop effective models of formation of event portfolio of the destination, as a set of events taking place in its territory, to find ways to optimize its structure and areas of influence.

Analysis of recent research and publications. The issue of event and event tourism as a factor of activation of tourist potential of the territory was raised in the works of D. Getz $[1 ; 2 ; 3]$ and developed in the research by A. Golob [4], V. Polishchuk, A. Babkin [5], O. Alekseeva [6]. For the first time in these works, the problems of eventual destination management were examined in the post-Soviet space. Also worth mentioning are some studies on the role of mega-agents in the economies of countries and regions (I. Skavronska, Van Miao, etc.) [7; 8], as well as the problems of socio-economic effects of certain types of events: exhibition (T. Duplyak) [9], cultural (A. Parfinenko) [10], gastronomic (V. Omilnitskaya [11]), sports (L. Tymoshenko [12]) and others.

However, despite the obvious increase in the interest of scholars and practitioners in eventual (event) tourism in the world and in Ukraine, a number of issues that have not received sufficient attention in the scientific literature remain. In particular, it is about planning an eventual destination portfolio as part of a local tourism product, which determines the relevance of this article.

The aim of the article is theoretical substantiation of the process of planning an eventual portfolio of destinations of Ukraine as a component of their tourism product.

Materials and methods. The work is based on the analysis of scientific works of domestic and foreign scholars on the problems of eventual tourism and the formation of eventual portfolio of tourist destinations. In the process of researching of eventual portfolios of tourist destinations in Ukraine such scientific and empirical methods as cause and effect analysis and synthesis, deduction and induction, systematization and generalization, as well as a systematic approach were used. 
Results. The term "eventual tourism" ("event tourism", "event tourism") was introduced into scientific circulation in 1989 when D. Getz in his work "Special Events: Product Definition" proposed a methodological basis for planning of event tourism [1, p. 135]. Nowadays, the term is interpreted as the term "tourist offer", which defines all planned activities within the framework of a comprehensive approach to the development and marketing of tourist territories/destinations, and as a component of tourist demand, that is, a special type of tourism, the development of which is driven by special needs of the visitors on a particular territory [2, p. 17]. Event is the basis of event tourism, the main factor of its development, actually, the reason for the trip or the supporting factor of decision making for the visitor.

An example of the successful implementation of the destination tourism development strategy was the research conducted during July-August 2018 by EFFE-Hub-Ukraine with the support of the European Association of Festivals under the project "Europe supports festivals, festivals support Europe" (EFFE). This project initiated a festival survey, cultural heritage, tourism, and community development [13]. The purpose of the survey was to determine the willingness to cooperate with festivals, tourism organizations, communities, evaluate and identify ways to improve cooperation between different sectors and stakeholders, as well as international cooperation, with the proposed issues addressing art festivals or those festivals where the component is a priority, and the secondary could be fair, gastronomic, sports and other components. The survey was attended by 324 respondents, including: 183 local communities, 65 - festival administrations and festival associations, 56 - travel companies and associations. According to the survey, 173 communities, 63 festival organizers and 55 tourism organizations have shown absolute confidence that festivals help attracting tourists to the community, and almost as many respondents consider events as an important community development tool. The survey organizers identified cultural heritage, multidisciplinary, musical, street art, ethnographic, literary, architecttural, film, photo, theater, dance and design activities, and respondents identified the top five as having the most potential for tourists. $42 \%$ of the surveyed tourist organizations found the best two-day event, $29 \%$ three-day, $11 \%$ one-day. It is important to note that both festival organizers and tourism companies have shown interest in cooperating with each other [14].

Combined with a certain logic and repeated with certain periodicity, the events carried out in the territory of the destination form the eventual portfolio (IP) of the latter.

The components of IPs within the concept of destination management have been customarily divided into events that equally reach both tourists and locals, and those whose purpose is to attract tourists in their own right. The last ones are commonly referred to as "hallmarks", that is, by J. Ritchie's definition, significant single or multiple events of a limited duration designed primarily to increase the attractiveness, profitability, and information of tourist destinations [15]. D. Getz elaborated on the definition of J. Ritchie, believing that the term "hallmark" describes an event of such importance 
in terms of traditions, attractiveness, quality, and publicity, which ensures the competitiveness of the destination where it is held [2, p. 16]. Over time, the event and the destination of the event become inseparable in the minds of the target markets, providing a high level of value.

Another thing is local and regional events (festivals, gatherings, contests, fairs, etc.), focused mainly on residents. Their main purpose is not commercialization, but rather they have certain cultural or social meanings. However, their level of organization or subject matter may be of some value to certain categories of tourists, stimulating tourist demand in that way. That is, it can be argued that such activities have unequal tourism potential, only some of them become or have the potential to become part of the tourist product of the destination. The other part not only lacks such potential but also has the opposite interest from tourists and could hurt them.

Modern scientific thought now links the sustainable development of tourism not so much with the conduct of a specific event or events, but with the planning, organization, and management of a set of such events within the framework of a single concept of a local tourism product [2]. Let us dwell more on planning an eventual portfolio and consider the possible goals of developing an IAP and approaches to making tactical decisions.

IP is part of the local tourism product and one of the tools of the destination marketing strategy. Accordingly, the purpose of its development should be correlated with the goals of socio-economic, narrower - marketing or tourism development strategy of the territory. The key determinant of goal setting is the life cycle stage of the destination (exploration, engagement, development, consolidation, stagnation, recovery/decline) and the needs that arise at each stage. One of the goals is the formation of a certain level of awareness of the target audience about the destination, interest or primary level of awareness of its resources, or tourist products. This goal is formulated either as a whole, for all target audiences or product components, or in specific contexts, for specific target audiences or resource types. Perception / Awareness of Target Audiences - setting destinations in the early stages of the life cycle or at the stage of consolidation when there is a need for diversification of the tourism product.

The specific task for the destination, especially relevant for many cities and villages in Ukraine, is to restore demand. Accordingly, the purpose of building an eventual portfolio is to restore the awareness/interest of target audiences.

Another goal for the development of IP may be to ensure a certain dynamics of tourist arrivals: increasing their number in general for the destination in specific periods of the year - to expand the main tourist seasons or to revive demand in the off-season; profit of specific target audiences - for restructuring of tourist flow.

Planning an eventual portfolio requires a number of tactical decisions about filling of it to be made.

The decision on the number of events during the year is dictated not only by the strategic goal, but also by the internal objective and subjective factors of the destination, the ability to generate financial resources, the avai- 
lability of human resources and appropriate management structure, the level of stakeholder interest, the availability of special infrastructure, specialization.

Decisions about the timing and distribution of events throughout the year also depend on the overall goals of the destination. Conducting activities during the main season create additional attractiveness of the territory, at the beginning and end of the season - contribute to its expansion, during the off-season - generally reduce the factor of seasonality.

Decisions of the scales of the events in portfolio, that is, the number of participants, the planned number of visitors, the duration of the individual events, and whether the event remains a local event or becomes a regional, national or international event, is one of the most difficult for the destination and requires many factors to be considered. In addition to these internal conditions of the destination, there is also the presence of strong stakeholders, the ability of the destination to ensure the environmental sustainability of the event, a variety of situational factors, including political. A separate aspect of this decision is to determine the feasibility of attracting eventual franchises.

Decisions to engage specific target audiences include, first of all, whether the planned events will be targeted primarily at visitors, or whether they will try to reach local residents as well.

The decision on the theme of events in the portfolio is made primarily with regard to the specialization of the destination, its historical, cultural, sports or economic background. One of the subordinated goals of developing an event portfolio for the destination is to involve certain categories of visitors, to create or change the image in the eyes of the target audiences, which also influences the inclusion of events on certain themes. Therefore, the destination can emphasize on narrow events, have a specialization, and can diversify its eventual portfolio, including very different activities.

According to the online portal zruchno.travel [14], eventual portfolios of some local destinations regarding tourist significant events that took place in Ukraine in 2018 were analyzed. The study has a number of objecttive limitations. Thus, the availability of event information on a resource depends on the activity of the event organizers who have to submit the data, as well as on the subjective decision of the resource administrators who make the decision to post the information. In addition, data on the Autonomous Republic of Crimea and parts of the territories of Donetsk and Luhansk regions are missing.

Thus, the absolute indicators for the number of events, including visitor-oriented events, are not conclusive for most destinations. In addition, the paper typifies the events proposed by the resource zruchno.travel.

According to zruchno.travel, such tourist destinations in Ukraine have event portfolios of at least 10 events included in the local tourism product (this is evidenced by the fact of posting event information on the Internet site of purely tourist specialization): Kyiv - 56 events during the year, Kamianets-Podilskyi - 35, theme park "Kievan Rus" in the village. Kopachi (Kyiv region) - 25, Lviv - 20, Zaporizhia - 18, Vinnytsia - 15, Lutsk - 15, Odessa -14 , Ternopil -13 , Kharkiv - 10. It is worth noting that among this 
group only Kamianets-Podilskyi is not a regional center, and the theme park "Kievan Rus" is a destination corporation. From 2 to 9 events have measures in their portfolio and take them for their promotion of the city: Dnipro, Ivano-Frankivsk, Uzhgorod, Poltava, Khmelnitsky, Kherson, Mykolayiv, Chortkiv, Trostyanets, Berezhany, Radomichel, Tulchin, Kryvyi Rih, Korosten, Beregove, township: Opishnaya, Medshibish. Another 60 tourist centers posted only one event on zruchno.travel information. Among regions most events are held in the territories of Kyiv and Khmelnitsky regions (85 and 44 respectively), while territorial differentiation is more typical of Ternopil and Transcarpathian regions (35 events in 16 destinations and 23 events in 11 destinations, respectively) (table 1).

Table 1

Events that were held in destinations of Ukraine during 2018

\begin{tabular}{|c|c|c|c|c|c|}
\hline Region* & Quantity & City & Quantity & Villages & Quantity \\
\hline \multirow{3}{*}{ Vinnytsia region } & \multirow{3}{*}{19} & Vinnytsia & 15 & Busha & 1 \\
\hline & & \begin{tabular}{|l} 
Tulchyn \\
\end{tabular} & 2 & - & - \\
\hline & & Bar & 1 & - & - \\
\hline \multirow[b]{2}{*}{ Volyn region } & \multirow[b]{2}{*}{16} & Lutsk & 15 & - & - \\
\hline & & \begin{tabular}{|l|} 
Volodymyr- \\
Volynskyi
\end{tabular} & 1 & - & \\
\hline \multirow{2}{*}{$\begin{array}{l}\text { Dnipropetrovsk } \\
\text { region }\end{array}$} & \multirow{2}{*}{6} & Dnipro & 3 & Petrykivka & 1 \\
\hline & & Kryvyi Rig & 2 & - & - \\
\hline \multirow{3}{*}{ Zhytomyr region } & \multirow{3}{*}{8} & Zhytomyr & 1 & Kostovtsi & 1 \\
\hline & & Radomyshl & 4 & - & - \\
\hline & & Korosten & 2 & - & - \\
\hline \multirow{6}{*}{$\begin{array}{l}\text { Transcarpathian } \\
\text { region }\end{array}$} & \multirow{6}{*}{23} & Uzhhorod & 8 & Chinadiyevo & 1 \\
\hline & & Berehove & 6 & Turya Polyana & 1 \\
\hline & & Vynohradiv & 1 & Kosiv Polyana & 1 \\
\hline & & Mukacheve & 1 & Veliatyno & 1 \\
\hline & & Rakhiv & 1 & Dubove & 1 \\
\hline & & Tiachiv & 1 & - & - \\
\hline \multirow{2}{*}{ Zaporizhzhia region } & \multirow{2}{*}{21} & Zaporizhzhia & 18 & Petropil & 2 \\
\hline & & Melitopol & 1 & - & - \\
\hline \multirow{3}{*}{$\begin{array}{l}\text { Ivano-Frankivsk } \\
\text { region }\end{array}$} & \multirow{3}{*}{8} & Ivano-Frankivsk & 4 & Starun & 1 \\
\hline & & Rogatyn & 1 & Velykyi Yaseniv & 1 \\
\hline & & - & - & Pidgirrya & 1 \\
\hline \multirow{3}{*}{ Kyiv region } & \multirow{3}{*}{85} & Kyiv & 56 & Kopachiv & 25 \\
\hline & & Bila Tserkva & 1 & Berezivka & 1 \\
\hline & & \begin{tabular}{|l|} 
Pereyaslav \\
Khmelnitsky \\
\end{tabular} & 1 & Boyarka & 1 \\
\hline \multirow{3}{*}{ Lviv region } & \multirow{3}{*}{30} & Lviv & 20 & Urych & 1 \\
\hline & & \begin{tabular}{|l|} 
Drogobych \\
\end{tabular} & 6 & Rodatychi & 1 \\
\hline & & Truskavets & 1 & Shidnytsia & 1 \\
\hline Mykolayiv region & 3 & Mykolayiv & 2 & Tryhaty & 1 \\
\hline \multirow{3}{*}{ Odessa region } & \multirow{3}{*}{18} & Odessa & 14 & Ivankiv & 1 \\
\hline & & \begin{tabular}{|l} 
Bolgrad \\
\end{tabular} & 1 & Vesele & 1 \\
\hline & & \begin{tabular}{|l|} 
Chernomorsk \\
\end{tabular} & 1 & - & - \\
\hline \multirow{4}{*}{ Poltava region } & \multirow{4}{*}{8} & Poltava & 2 & Opishnia & 2 \\
\hline & & \begin{tabular}{|l|} 
Myrhorod \\
\end{tabular} & 1 & Dykanka & 1 \\
\hline & & - & - & Omelnyk & 1 \\
\hline & & - & - & Hradyzk & 1 \\
\hline
\end{tabular}

ISSN 1727-9313. ВІСНИК КНТЕУ. 2020. 
Ending table 1

\begin{tabular}{|c|c|c|c|c|c|}
\hline Region* & Quantity & City & Quantity & Villages & Quantity \\
\hline \multirow{3}{*}{ Rivne region } & \multirow{3}{*}{4} & Ostrog & 1 & Berestechko & 1 \\
\hline & & - & - & Hotyn & 1 \\
\hline & & - & - & Klevan & 1 \\
\hline \multirow{3}{*}{ Sumy region } & \multirow{3}{*}{6} & Trostyanets & 3 & Slout & 1 \\
\hline & & Konotop & 1 & - & - \\
\hline & & Gluhiv & 1 & - & - \\
\hline \multirow{8}{*}{ Ternopil region } & \multirow{8}{*}{37} & Ternopil & 13 & Zaliztsi & 1 \\
\hline & & Chortkiv & 9 & Gusyatyn & 1 \\
\hline & & Berezhany & 3 & Monastyrske & 1 \\
\hline & & Zboriv & 1 & Zalizshiki & 1 \\
\hline & & Terebovlya & 1 & Nyrkiv & 1 \\
\hline & & Skalat & 1 & Pidzamochok & 1 \\
\hline & & \begin{tabular}{|l|} 
Borschiv \\
\end{tabular} & 1 & Gorodok & 16 \\
\hline & & - & - & Kozova & 1 \\
\hline \multirow{3}{*}{ Kharkiv region } & \multirow{3}{*}{14} & Kharkiv & 10 & Staryi Saltiv & 1 \\
\hline & & Zmiiv & 1 & Sharivka & 1 \\
\hline & & - & - & Zadonetske & 1 \\
\hline \multirow{2}{*}{ Kherson region } & \multirow{2}{*}{5} & Kherson & 4 & - & - \\
\hline & & \begin{tabular}{|l|} 
Gola Prystan \\
\end{tabular} & 1 & - & - \\
\hline \multirow{3}{*}{ Khmelnytsk region } & \multirow{3}{*}{44} & Kamianets Podilskyi & 35 & Medzhybizh & 3 \\
\hline & & Khmelnytskyi & 5 & - & - \\
\hline & & Izyaslav & 1 & - & - \\
\hline \multirow{4}{*}{ Cherkasy region } & \multirow{4}{*}{11} & Uman & 6 & Legedzyne & 2 \\
\hline & & - & - & Melnyky & 1 \\
\hline & & - & - & Moryntsi & 1 \\
\hline & & \begin{tabular}{|l}
- \\
\end{tabular} & - & Buda & 1 \\
\hline \multirow{2}{*}{ Chernivtsi region } & \multirow{2}{*}{5} & Chernivtsi & 3 & Vyzhnytsia & 1 \\
\hline & & - & - & Shepit & 1 \\
\hline \multirow{5}{*}{ Chernihiv region } & \multirow{5}{*}{23} & Chernihiv & 14 & Sosnytsia & 1 \\
\hline & & Baturyn & 3 & Oleshnia & 1 \\
\hline & & \begin{tabular}{|l|} 
Novgorod-Siversky \\
\end{tabular} & 1 & Sedniv & 1 \\
\hline & & \begin{tabular}{|l|} 
Nizhyn \\
\end{tabular} & 1 & - & - \\
\hline & & Mena & 1 & - & - \\
\hline Donetsk region & 1 & Mariupol & 1 & - & - \\
\hline
\end{tabular}

* Except Crimea, Lugansk and Kirovograd regions, which are not represented on the resource https://zruchno.travel.

Source: compiled by the authors according to the data [15].

The size of the event portfolios and the available information on their topic-types determined the choice for further analysis of the destinations of the first group (except the theme park "Kyiv Rus"). Thus, the peaks of eventual activity of the research of destinations are April-May and SeptemberOctober (figure), which is obviously connected with the climatic conditions and rest traditions of Ukrainians, more rarely - the desire to extend tourist seasons or to activate the flow of tourists in the off-season. The most balanced portfolios in time have Kyiv, Lviv and Kamianets-Podilskyi. 


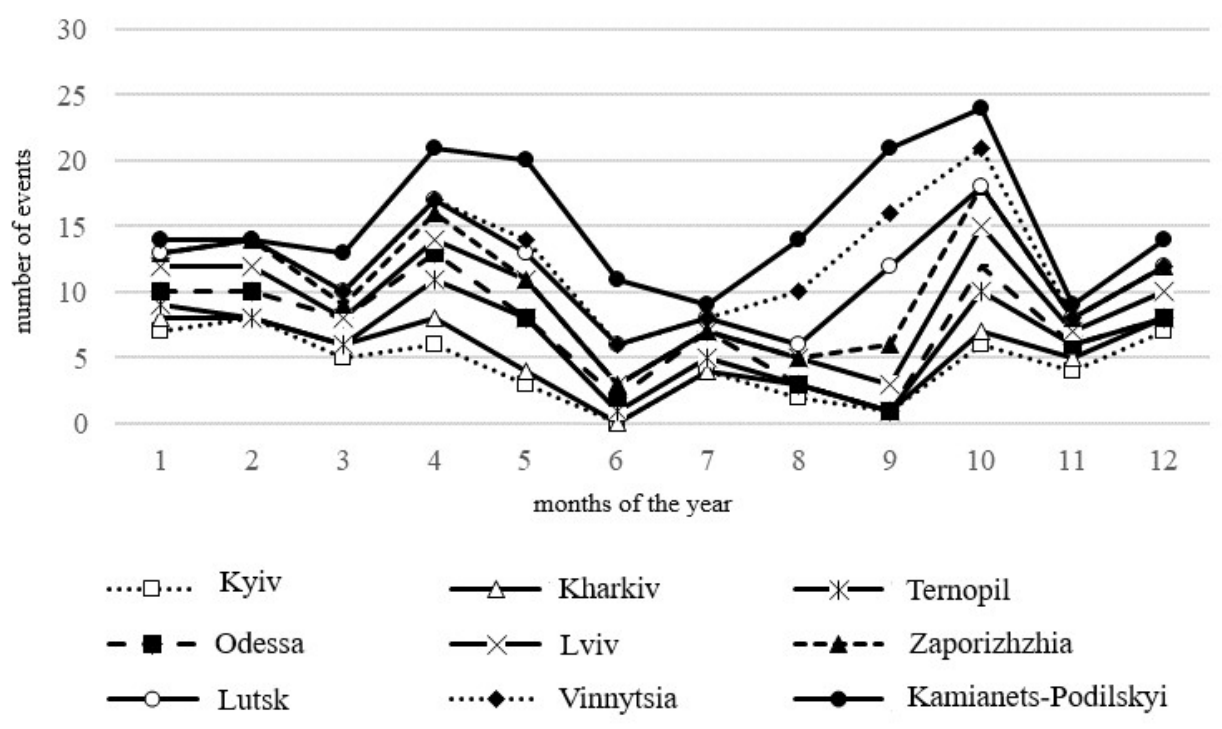

The dynamic of events in destinations in Ukraine in 2018

Source: compiled by the authors according to the data [15].

In the structure of eventual portfolios, nine explored destinations are on average up to $30 \%$ occupied by cultural events, $17 \%$ by music, $12 \%$ by sports, $11 \%$ by city holidays, $10 \%$ by gastronomic events, $9 \%$ by historical, $6 \%$ are ethnographic, $5 \%$ are religious, $2 \%$ are so-called "retro" events, but regional differences are very significant here (table 2). The undisputed leader is Kamianets-Podilskyi, whose event portfolio includes activities in all thematic areas, except religious ones.

Table 2

The structure of eventual portfolio of destinations of Ukraine by topic, \%

\begin{tabular}{|c|c|c|c|c|c|c|c|c|c|}
\hline The theme of the event & $\stackrel{\vec{\Delta}}{\vec{\lambda}}$ & 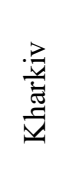 & $\begin{array}{l}\overline{\bar{O}} \\
\stackrel{0}{0} \\
\stackrel{0}{\oplus}\end{array}$ & 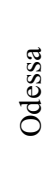 & 尝 & 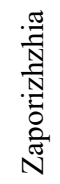 & 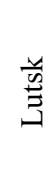 & 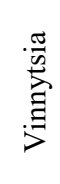 & 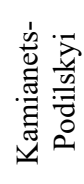 \\
\hline Gastronomic & 8 & 11 & 15 & 0 & 29 & 0 & 13 & 7 & 3 \\
\hline Cultural & 40 & 22 & 31 & 33 & 24 & 31 & 20 & 21 & 31 \\
\hline Music & 19 & 0 & 15 & 8 & 19 & 31 & 13 & 29 & 22 \\
\hline City holiday & 4 & 11 & 8 & 25 & 14 & 13 & 7 & 14 & 6 \\
\hline Historical & 4 & 0 & 8 & 0 & 0 & 0 & 40 & 7 & 19 \\
\hline Retro & 2 & 11 & 0 & 0 & 0 & 0 & 0 & 0 & 3 \\
\hline Sports & 0 & 33 & 0 & 25 & 5 & 19 & 0 & 14 & 13 \\
\hline Ethnographic & 17 & 11 & 23 & 0 & 5 & 0 & 0 & 0 & 3 \\
\hline Religious & 6 & 1 & 0 & 9 & 4 & 6 & 7 & 8 & 0 \\
\hline
\end{tabular}

Source: compiled by authors according to the data [15].

The substantial analysis of the eventual portfolios of Ukraine's regions showed the inability to determine the potential of existing, tradetional measures, their exclusive orientation to the socio-cultural aspects, to the domestic consumer (local resident). Of course, there are hundreds of local 
or regional events that are planned annually in the framework of regional or local plans and programs for the development of culture, sports, health and leisure in most cities of Ukraine, but the level of organization and marketing of the vast majority of them is extremely local with a rather powerful tourist potential (example - "Songs of lilac grove" festival smt. Dykanka of Poltava region), which makes it impossible to achieve certain tourist, and therefore economic and even political goals. The optimal strategy in this sense is, according to D. Getz, the transformation of existing events with certain characteristic features into tourist attractions of the destination within the overall branding strategy and taking into account the opportunities for economic growth of the territory [2, p. 407]. A similar approach is demonstrated by the Savransky district of Odessa region, where within the framework of the event concept "4 seasons" a number of traditional events, focused on attracting guests from neighboring regions, have been held for several years in a row.

The research results indicate that there is no logical network institutionalization of the events when their organizers are exclusively relevant authorized organizations and institutions, that is, the priority is the corporate orientation of the event organization. For example, in Ukraine we are dealing with activities under the auspices of the departments and departments of culture, sport, education, health, each of which considers the purpose of its own event purely in the narrow sense and under its own control. Instead, global experience confirms that the optimal format is to apply a networked approach to institutionalization, whereby a reconciliation of eventual portfolio and event marketing aimed at attracting visitors is undertaken by the tourism management body.

Conclusion. The research has shown that the formation of an eventual portfolio of tourist destinations should take place within the existing socio-economic and tourism development strategies. The purpose of the eventual portfolio should be to create / restore awareness / interest of target audiences, or to ensure a certain dynamics of tourist income. Filling an event portfolio means, first of all, making a number of decisions about the number of events, their dynamics and seasonality, scale, topics. A balanced event portfolio should be considered as one that ensures the achievement of the strategic goals of the destination during the year by organizing and conducting events that are most relevant to the interests of the target audience of the visitors.

Nowadays, portfolios of Kyiv, Lviv and Kamianets-Podilskyi have signs of balance in Ukraine. The most important tasks of optimizing the eventual policy of tourist destinations of Ukraine are now the transformation of existing local events into tourist attractions within the overall branding strategy and taking into account the possibilities of economic growth of the territory, as well as the institutionalization of planning of the eventual portfolio. 


\section{REFERENCES}

1. Getz, D. (1989). Special events: Defining the product. Tourism Management. 10(2). 135-137 [in English].

2. Getz, D. (2007). Event studies: Theory, research and policy for planned events. Oxford: Elsevier [in English].

3. Getz, D. (2008). Event tourism: Definition, evolution, and research. Tourism Management, 29, 403-428 [in English].

4. Golob, A., Jere, Jakulin T. (2014). Standardization and classification of events in tourism. The European Journal of Applied Economics. (Vol. 14), 1. Retrieved from http://journal.singidunum.ac.rs/paper/standardization-and-classificationof-events-in-tourism-based-on-a-systems-approach.html [in English].

5. Babkin, A. V. (2008). Special'nye vidy turizma [Special types of tourism]. Rostov n/D: Feniks [in Russian].

6. Alekseeva, O. V. (2011). Sobytijnyj turizm i ivent-menedzhment [Event tourism and event management]. Rossijskoe predprinimatel'stvo - Russian business, 6 . Issue 2 (186), 167-172 [in Russian].

7. Vasilenko, V. A., \& Van', Mjao (2011). Osnovy teorii i praktiki sportivnosobytijnogo turizma [Fundamentals of the theory and practice of sports and event tourism]. Simferopol': Krymuchpedgiz [in Russian].

8. Skavrons'ka, I. V., Bulatova, O. V., Kozak et al. (2014). Mizhnarodni megazahody: sportyvnyj aspekt. Novyj svitovyj ekonomichnyj porjadok ta global'ni vyklyky dlja Ukrai'ny [International Mega-Events: the Sport Aspect. A New World Economic Order and Global Challenges for Ukraine]. Krysovatyj A., Savel'jev Je. (Eds.). Ternopil': TNEU [in Ukrainian].

9. Tkachenko, T. I., \& Dupljak, T. P. (2016). Vystavkovyj biznes [Exhibition business]. Kyi'v: Kyi'v. nac. torg.-ekon. un-t [in Ukrainian].

10. Parfinenko, A. Ju. (2013). Kul'turnyj turyzm jak chynnyk social'no-ekonomichnogo rozvytku terytorij [Cultural Tourism as a Factor of Socio-Economic Development of Territories]. Visnyk L'vivs'kogo universytetu - Visnyk of the Lviv University. Issue 43, 233-242. Serija geografichna [in Ukrainian].

11. Omel'nyc'ka, V. O. (2018). Suchasnyj stan rynku poslug gastronomichnogo turyzmu Ukrai'ny [The Current State of the Gastronomic Tourism Services Market in Ukraine]. Ekonomichni studii' - Economic Studies, 2, 121-126 [in Ukrainian].

12. Tymoshenko, L. O., \& Labartkava, K. V. (2014). Sportyvnyj turyzm [Sports tourism]. L'viv: LDUFK [in Ukrainian].

13. Rol' mystec'kyh festyvaliv u samorozvytku gromad. Monitoryng praktychnyh pytan' [The Role of Art Festivals in Community Self-development. Monitoring of Practical Issues]. demcult.org. Retrieved from http://demcult.org/rol-misteckikhfestivaliv-u-samoroz [in Ukrainian].

14. Nacional'nyj turystychnyj portal Zruchno.Travel [National Tourism Portal Zruchno.Travel]. zruchno.travel. Retrieved from https://zruchno.travel [in Ukrainian].

15. Ritchie, J. R. B., \& Beliveau, D. (1974). Hallmark events: An evaluation of a stratewgic response to seasonality in the travel market. Journal of Travel Research, 14, 14-20 [in English].

The article submitted to editor's office on 16.01.2020.

ISSN 1727-9313. ВІСНИК КНТЕУ. 2020. 
Михайліченко Г., Кравцов С., Забалдіна Ю. Планування івентивного портфеля туристичної дестинації у посткарантинний період.

Постановка проблеми. Для успішного розвитку туристичних дестинацій, широкої обізнаності изільових аудиторій щзодо території необхідно проведення масових заходів різної тематики. Це дасть змогу акумулювати додаткові туристичні потоки через диверсифікацію пропозииії для більш розвинених дестинацій, визначити туристичну спеціалізацію території. Починаючи з 80-х років XX ст., івенти стали водночас невід'ємною складовою локального туристичного продукту й елементом маркетингових стратегій для багатьох дестинацій світу. Такі тенденції диверсифікації туристичного продукту дестинації особливо актуальні в посткризовий період реінкарнації туристичної сфери після значної стагнації під час карантинних заходів пандемії коронавірусної інфекиії в 2020 р. Дієвість івент-програм як елемента індустрії МІСЕ може стати поштовхом до відтворення атрактивності провідних дестинацій світу. Це поставило перед фахівиями завдання розроблення ефективних моделей формування івентивного портфеля (event portfolio) дестинаціi як сукупності подій, щзо проводяться на ї̈ території, пошуку шляхів оптимізації його структури та напрямків впливу.

Аналіз останніх досліджень $і$ публікацій показав, щзо попри наявність окремих наукових доробок та очевидне зростання інтересу науковців і практиків до івентивного (подієвого) туризму в світі і в Україні, існує низка питань, яким не приділено достатньої уваги в науковій літературі. Зокрема, йдеться про планування івентивного портфеля дестинації як складової локального туристичного продукту, щзо і визначає актуальність иієї статті.

Метою статті є теоретичне обтрунтування процесу планування івентивного портфеля дестинацій України як складової їх туристичного продукту.

Матеріали та методи. Робота трунтується на аналізі наукових праць вітчизняних та зарубіжних учених щодо проблем івентивного туризму та формування івентивного портфеля туристичних дестинацій. В процесі дослідження івентивних портфелів туристичних дестинацій Украӥни використано такі науково-емпіричні методи, як причинно-наслідковий аналіз та синтез, дедукиія та індукція, систематизація та узагальнення, а також системний підхід.

Результати дослідження. Зміст робіт з формування івентивного портфеля туристичної дестинації передбачає: визначення кількості й тематики івентів; періодичності та тривалості подій, встановлення масштабності заходу, тобто дочільності залучення івентивних франшиз; рішення щэодо залучення певних цілььових аудиторій та вплив спеціалізації дестинації.

Здійснено теоретичне обтрунтування прочесу планування івентивного портфеля дестинацій Украӥни як складової їх туристичного продукту. Визначено иілі формування івентивного портфеля дестиначії в рамках стратегії формування туристичного продукту та маркетингової стратегії. Виділено чинники прийняття рішень щзодо структури івентивного портфеля, динаміки заходів.

Проаналізовано пропориійність івентивних портфелів туристичних дестинацій України. Проведене дослідження довело, щзо формування івентивного портфеля туристичних дестинацій повинно відбуватись у рамках існуючих соціально-економічних стратегій і стратегій розвитку туризму. Метою, на яку має бути спрямований івентивний портфель, може бути створення/відновлення рівня обізнаності/ зацікавлення иільових аудиторій або ж забезпечення певної динаміки туристичних прибуттів. Збалансованим івентивним портфелем варто вважати такий, щуо забезпечує реалізацію стратегічних иілей дестинації упродовж року иляхом організаціі та проведення заходів, тематика яких максимально задовольняє інтереси иільових аудиторій відвідувачів. На території України ознаки збалансованості наразі мають івентивні портфелі міст Києва, Львова та Кам'яния-Подільського. Найважливішими завданнями оптимізаиї̈ івентивної політики туристичних дестинацій Украӥни 
наразі є перетворення існуючих локальних подій на туристичні атрактори в рамках загальної стратегії брендингу $i$ з урахуванням можливостей економічного зростання території, а також інституалізація процесу планування івентивного портфеля.

Висновки. На відміну від існуючих публікацій, вперше сформульовано наукові гіпотези залежності туристичних потоків дестинаиї від розвитку івент-туризму. Проведене дослідження показало, шьо формування івентивного портфеля туристичних дестинацій має відбуватись у рамках наявних соиіально-економічних стратегій i стратегій розвитку туризму. Метою, на яку має бути спрямований івентивний портфель, може бути створення/відновлення рівня обізнаності/зацікавлення ціільових аудиторій або ж забезпечення певної динаміки туристичних прибуттів. Наповнення івентивного портфеля означає насамперед прийняття низки рішень щзодо кількості івентів, їх динаміки та сезонності, масштабу, тематики. Збалансованим івентивним портфелем варто вважати такий, що забезпечує реалізацію стратегічних цүілей дестинації упродовж року шляхом організації та проведення заходів, тематика яких максимально задовольняє інтереси ичільових аудиторій відвідувачів.

Ключові слова: дестинація, івенти, івентивний туризм, івентивний портфель, туристичний продукт, холмарк, туристичний потік, туристичні прибуття. 